\title{
David Oliver: Will we now see a serious attempt to tackle social care funding?
}

\author{
David Oliver consultant in geriatrics and acute general medicine
}

Berkshire

In Theresa May's January reshuffle of her cabinet, Jeremy Hunt received an upgrade to his job title: "and social care" was appended to "secretary of state for health." Is this a cosmetic change, or does it indicate a real desire to drive through meaningful reform?

For several parliaments, ministerial and civil service responsibility for social care has been shared with two other ministries, but mainly it's been with the Department of Health. Social care will reportedly now be brought entirely into the Department of Health, with Hunt leading an inquiry into future funding and provision. ${ }^{2}$

Over the past two decades we've seen several diligent commissions make recommendations that no one had the political courage to implement: for instance, the Sutherland Commission in $1999^{3}$ or the King's Fund Barker Commission in 2014. ${ }^{4}$ The economist Andrew Dilnot, in his 2011 government commission on social care funding, recommended a public-personal partnership with a cap for maximum expenditure, ${ }^{5}$ but the idea was never implemented and was recently terminated by ministers. ${ }^{6}$

The Care Act 2014 is an excellent piece of legislation in terms of rights and responsibilities in adult social care and support for carers, but it lacks the funding to make its principles and ambitions a reality for people needing social services. ${ }^{78}$ We've seen the same mismatch between rhetorical soundbites and the required workforce and funding to make them a reality, in government pledges on "parity of esteem" in mental health services ${ }^{9}$ and on making the NHS the "safest in the world."10

The public debate around social care is not helped by a childish media narrative where reasonable suggestions are strangled at birth with headlines about a "death tax" or a "dementia tax." 11-14 National policy often treats social care only in relation to what it can do to help the NHS: additional funding has been heavily attached to targets for reducing strain on hospitals, ${ }^{15}$ and the recent Health Education England workforce strategy said little coherent on the social care workforce. ${ }^{16}$ Beyond this, since 2010 we've seen a calculated and deliberate attack on local government funding and, hence, social care. ${ }^{17}$
Before Hunt's expanded role the government had announced a green paper by summer 2018 on care and support for older people. ${ }^{18}$ But its expert reference group comprises several people long associated with the current muddle, and it has little carer or user representation. ${ }^{19}$ It won't deal with social care for younger adults or children, and it will take some time to reach the white paper stage, let alone legislative stages, with Brexit dominating parliamentary business.

This dilettante, "too difficult" approach from successive governments is too little, too late. The problems facing the social care system are just the kind of thorny issue we elect governments and employ civil servants to solve. I would salute Hunt if we could break this cycle of denial and delay. But history tells us that, however good the plans, the Treasury will have the final say and may block them yet again. I hope that we're on the threshold of meaningful reform — but I'm not holding my breath.

Merrick R. Jeremy Hunt keeps Heath Secretary with added social care brief despite overseeing NHS "winter crisis." 8 Jan 2018. http://www.independent.co.uk/news/uk/politics/ jeremy-hunt-heath-secretary-social-care-nhs-winter-crisis-cabinet-reshuffle-theresa-maybrexit-a8148331.html.

2 Department of Health and Social Care. Health secretary urges people to talk to each other about organ donation. 12 Dec 2017. https://www.gov.uk/government/organisations/ department-of-health-and-social-care

3 Social Care Institute for Excellence. With respect to old age: long term care; rights and responsibilities; the context of long-term care policy; research volume 1: a report by the Royal Commission on Long Term Care. 1999. https://www.scie-socialcareonline.org.uk/ search?q=author_name:\%22great+britain.+royal+commission+on+long+term+care\%22. King's Fund. Illustrated summary of the Barker Commission's final report. Sept 2014. https://www.kingsfund.org.uk/publications/new-settlement-health-and-social-care/summary? gclid=EAlalQobChMlte228dnP2AIVCz8bCh2RwACMEAAYASAAEgITOvD_BwE.

5 King's Fund. Briefing: the Dilnot Commission report on social care. 13 July 2011. https:/ /www.kingsfund.org.uk/sites/default/files/field/field_publication_file/briefing-dilnotcommission-social-care-jul11.pdf.

6 Paine D. Government ditches cap on social care costs. 7 Dec 2017. https://www.hsj.co. uk/policy-and-regulation/government-ditches-cap-on-social-care-costs/7021252.article [login needed].

Carers UK. Care Act FAQ. 2014. https://www.carersuk.org/help-and-advice/practicalsupport/getting-care-and-support/care-act-faq?

gclid=EAlalQobChMlhKubvtrP2AIViBgbCh1xegzSEAAYASAAEgLMi_D_BwE.

8 King's Fund. Social care for older people: home truths. 15 Sept 2016. https://www. kingsfund.org.uk/publications/social-care-older-people.

Naylor C. Is there "parity of esteem" between mental and physical health? Big election questions. 19 May 2017. https://www.kingsfund.org.uk/publications/articles/big-electionquestions-parity-mental-physical-health. 
10 Hunt: "We can turn NHS into safest healthcare system in world." BBC News 26 March 2014. http://www.bbc.co.uk/news/av/health-26744613/hunt-we-can-turn-nhs-into-safesthealthcare-system-in-world

11 Watt N. Spectre of "death tax" haunts Andy Burnham's care revolution. Guardian 30 March 2010. https://www.theguardian.com/politics/2010/mar/30/death-tax-haunts-andy-burnhamcare-revolution.

12 EatonG. The Tories' new poster: myth and reality. New Statesman2010;10. https://www. newstatesman.com/blogs/the-staggers/2010/02/death-tax-labour-tories-attack.

13 King's Fund. Theresa May is right to drop the "dementia tax" needs considered reform. 22 May 2017. https://www.kingsfund.org.uk/publications/articles/ theresa-may-right-to-drop-dementia-tax? gclid=EAlalQobChMlifOOiNvP2AIVwSnTChOYigTCEAAYASAAEgLThPD_BwE.

14 Elgot J. Homes are not assets to be passed on to children, says minister. Guardian 12 Oct 2017. https://www.theguardian.com/society/2017/oct/12/labour-accuses-tories-ofreviving-dementia-tax-after-ministers-property-remarks.

15 OliverD. David Oliver: Is the NHS trying to help or bully social care?BMJ2017;358:j3623. doi:10.1136/bmj.j362328765107
16 Health Education England. Workforce strategy. https:/hee.nhs.uk/our-work/planningcommissioning/workforce-strategy.

17 Charlesworth A, Firth Z, Fisher R, et al; Health Foundation. The social care funding gap: implications for local health care reform. March 2017. http://www.health.org.uk/publication/ social-care-funding-gap-implications-local-health-care-reform?

gclid=EAlalQobChMl89zDoffP2AIVbQDTCh0RvgmWEAAYAiAAEgJ1bfD_BwE.

18 Green D, Cabinet Office Government to set out proposals to reform care and support. 16 Nov 2017. https://www.gov.uk/government/news/government-to-set-out-proposals-toreform-care-and-support

19 Gelb B. Why is the government ignoring the crisis facing children's social care? Guardian 27 June 2017. https://www.theguardian.com/social-care-network/2017/jun/27/social-caregreen-paper-queens-speech-funding-childrens-services.

Published by the BMJ Publishing Group Limited. For permission to use (where not already granted under a licence) please go to http://group.bmj.com/group/rights-licensing/ permissions 